\title{
RANCANG BANGUN SISTEM PENGOLAH DATA SENSUS PENDUDUK BERBASIS MULTI USER DI KECAMATAN MEDAN KOTA
}

\author{
Khairuddin Nasution ${ }^{1}$, Antoni $^{2}$ \\ ${ }^{1}$ Dosen Tetap Teknik Informatika Universitas Islam Sumatera Utara (UISU) \\ JL.Sisingamangaraja Kampus UISU Teladan, Kota Medan, Sumatera Utara 20217 \\ Khairuddin_nst@uisu.ac.id \\ ${ }^{2}$ Dosen Tetap Teknik Informatika Universitas Islam Sumatera Utara (UISU) \\ JL.Sisingamangaraja Kampus UISU Teladan, Kota Medan, Sumatera Utara 20217
}

\begin{abstract}
Abstrak - Penelitian ini dibuat untuk aplikasi sistem yang dapat digunakan dengan mudah dalam melakukan pekerjaan dan mendukung dalam pengambilan keputusan. Bahasa pemograman yang dipakai adalah Delphi dan untuk databasenya menggunakan MySql. Aplikasi berbasis multiuser ini digunakan untuk menganalisis dan memproyeksi tingkat pertumbuhan penduduk, melakukan pencarian penduduk dengan lebih cepat,memberikan suatu pemetaan kepadatan penduduk serta dapat menentukan perhitungan jumlah penduduk.
\end{abstract}

Keywords— penduduk, aplikasi, multiuser.

\section{PENDAHULUAN}

Kecamatan Medan kota merupakan suatu wilayah padat data kependudukan, khususnya para perencana, pengambil kebijaksanaan, dan peneliti sangat membutuhkan data penduduk yang berkesinambungan dari tahun ke tahun. Padahal sumber data penduduk yang tersedia hanya secara periodik, yaitu Sensus Penduduk (SP) pada tahun-tahun yang berakhiran dengan angka 0 (nol) dan Survei Penduduk Antar Sensus (SUPAS) pada pertengahan dua sensus atau tahun-tahun yang berakhiran dengan angka 5 (lima). Sumber data kependudukan yang lain yaitu registrasi penduduk masih belum sempurna cakupan pencatatannya sehingga datanya belum dapat digunakan untuk perencanan pembangunan nasional.

Seperti diketahui bahwa hampir semua rencana pembangunan perlu ditunjang dengan data jumlah penduduk, persebaran dan susunannya menurut umur penduduk yang relevan dengan rencana tersebut. Data yang diperlukan tidak hanya keadaan pada waktu rencana itu disusun, tetapi juga informasi perkiraan pada waktu yang akan datang. Data penduduk pada waktu yang lalu dan waktu kini dapat diperoleh dari survei dan sensus, sedangkan untuk memenuhi kebutuhan data penduduk pada masa yang akan datang perlu dibuat proyeksi penduduk yaitu perkiraan jumlah penduduk dan komposisinya di masa mendatang.

Proyeksi penduduk bukan merupakan ramalan jumlah penduduk tetapi suatu perhitungan ilmiah yang didasarkan pada asumsi dari komponen-komponen laju pertumbuhan penduduk, yaitu kelahiran, kematian dan perpindahan (migrasi). Ketiga komponen inilah yang menentukan besarnya jumlah penduduk dan struktur umur penduduk di masa yang akan datang. Untuk menentukan asumsi dari tingkat perkembangan kelahiran, kematian dan perpindahan di masa yang akan datang diperlukan data yang menggambarkan tren di masa lampau hingga saat ini.

\section{TINJAUAN PUSTAKA}

A. Sistem

Sistem merupakakn sekumpulan elemen - elemen yang saling berkaitan dan memproses masukan (input) sehingga menghasilkan keluaran (output)". Pengertian sistem dibagi menjadi dua pendekatan yaitu dilihat dari pendekatan yang menekankan pada prosedur dan di lihat dari pendekatan yang menekankan pada elemen atau komponen. Pendekatan sistem yang lebih menekankan pada prosedur didefinisikan suatu sistem adalah jaringan kerja dari prosedur - prosedur yang saling berhubungan, berkumpul bersama - sama untuk melakukan suatu kegiatan untuk menyelesaikan sasaran tertentu. Pendekatan sistem yang lebih menekankan pada elemen atau komponen didefinisikan sistem menurut Jogianto adalah sekumpulan dari elemen - elemen yang berinteraksi untuk mencapai suatu tujuan tertentu. (Jogiyanto, 2010). Dari kedua pengertian diatas sistem adalah suatu kesatuan yang terorganisasi dan tidak bisa berdiri sendiri yang saling berkaitan satu sama lain sesuai dengan rencana untuk mencapai tujuan tertentu.

Bentuk umum dari suatu sistem terdiri atas masukan (input), proses dan keluaran (output), dalam bentuk umum sistem ini terdapat satu atau lebih masukan yang akan diproses dan akan menghasilkan suatu keluaran seperti pada gambar 1 .

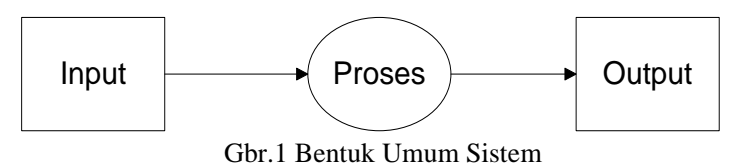

Gbr.1 Bentuk Umum Sistem 


\section{B. Sistem Informasi}

Sistem Informasi merupakan suatu sistem yang dibuat oleh manusia yang terdiri atas komponen komponen dalam organisasi untuk mencapai suatu tujuan yaitu menyajikan informasi. Sistem informasi merupakan kombinasi dari manusia, fasilitas atau alat teknologi, media, prosedur dan pengendalian yang bermaksud untuk menata jaringan komunikasi yang penting, pengolahan atas interaksi - interaksi tertentu dan rutin, membantu memanajemen dan menyediakan dasar pengambilan keputusan yang tepat. (Jogiyanto, 2010).

Informasi yang dihasilkan dari sistem informasi bertujuan untuk :

1. Menyediakan informasi untuk membantu dalam pengambilan mentukan jumlah penduduk oleh pihak yang berwenang.

2. Membantu petugas di dalam melaksanakan proses pengambilan data.

3. Memberikan informasi yang layak dan dapat dipertanggungjawabkan kepada pihak di luar organisasi.

\section{METODE PENELITIAN}

\section{A. Analisis Sistem}

Analisis dimulai dari pengamatan apa yang dibutuhkan, Kecamatan Medan Kota yang membutuhkan suatu aplikasi yang memudahkan dalam pengolahan data kependudukan karena dalam fungsinya hanya untuk memproses data yang ada di Kecamatan Medan kota. Berbagai informasi yang diperlukan oleh Kecamatan Medan Kota untuk diimplementasikan ke dalam aplikasi pengolahan data kependudukan tersebut adalah:

1. Data pegawai/user yang akan menjadi administrator.

2. Data kependudukan berdasarkan jumlah kategori, umur, profesi, kewarganegaraan, agama.

\section{B. Diagram Konteks}

Diagram konteks merupakan pola penggambaran sistem secara umum yang berfungsi untuk menggambarkan memperlihatkan interaksi antara sistem informas itersebut dengan lingkungan dimana sistem tersebut ditempatkan. Dalam diagram konteks, sistem dianggap sebuah objek yang tidak dijelaskan secara rinci karena yang ditekankan adalah interaksi sistem dengan lingkungan yang akan mengakses sistem tersebut.

Diagram konteks memiliki kelompok pemakai, baik pihak internal maupun pihak eksternal organisasi yang biasa disebut entitas luar. Diagram konteks memberikan gambaran seperti apa hubungan interaksi antara entitas luar dengan sistem, hubungan tersebut digambarkan dengan aliran data yang mengalir dari lingkungan luar sistem (entitas luar ) ke dalam sistem atau sebaliknya.

Ada satu entitas luar yang terlibat dalam sistem perpustakaan yaitu administrator. Fungsi dari diagram konteks adalah untuk memperjelas gambaran mengenai interaksi yang berlangsung di dalam sistem secara umum. Untuk member gambaran yang lebih jelas mengenai sistem perpustakaan yang sedang berjalan di Kecamtan Medan Kota, berikut diagram konteks Sistem Pengolahan Data Kependudukan di Kecamatan Medan Kota.Diagram konteks sistem Pengolahan data Kependudukan dapat dilihat pada gambar 2.

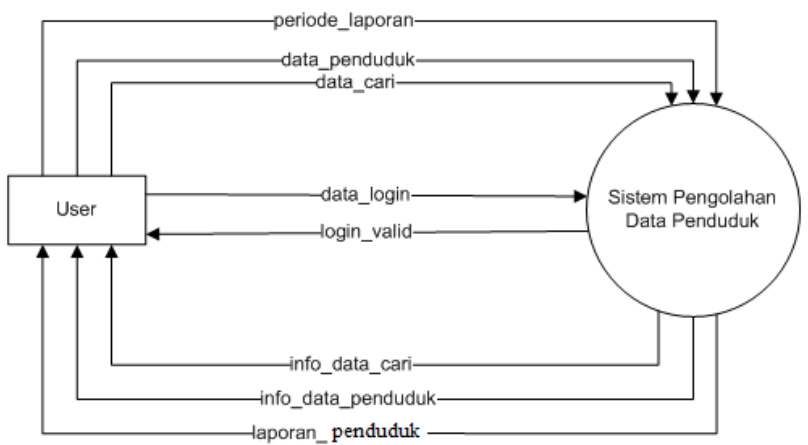

Gbr.2 Diagram konteks sistem Pengolahan data Kependudukan

\section{Data Flow Diagram (DFD)}

FD merupakan alat yang dapat menggambarkan arus data di dalam sistem secara terstruktur dan jelas, serta dokumentasi dari sistem yang baik. DFD suatu level dapat diturunkan menjadi level berikutnya.

DFD Level 1

Dalam DFD level 1 terdapat 4 proses yaitu, login, Pengolahan data penduduk, perpindahan dan laporan. DFD level 1 dapat dilihat pada gambar dibawah ini :

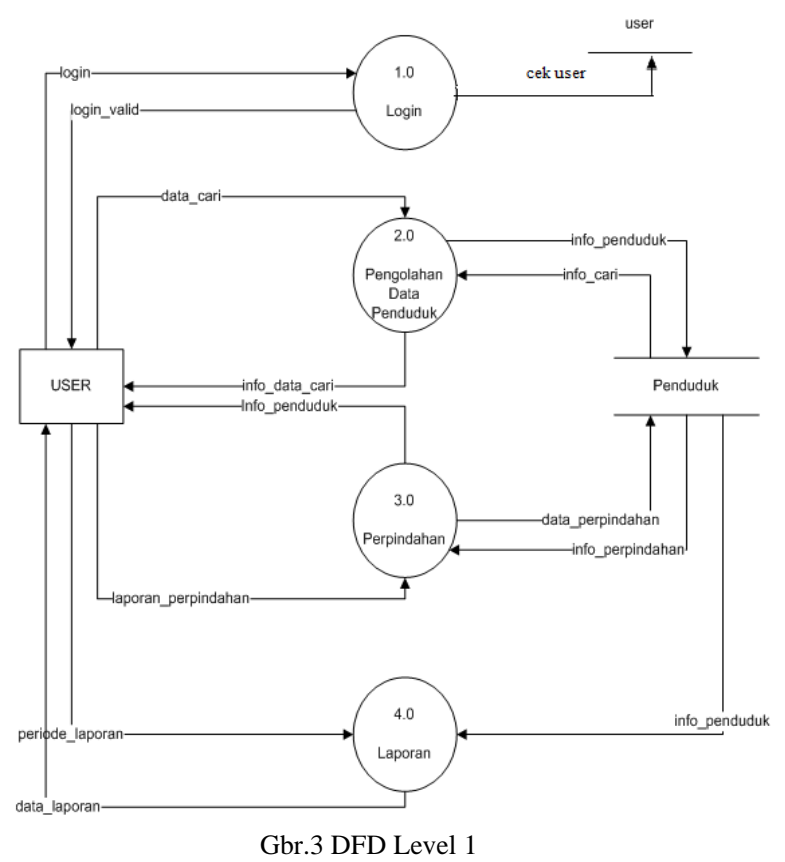

DFD level 2 proses 1.0

Proses pertama adalah login, digunakan untuk masuk ke halaman utama. Pada proses ini terdapat dua proses utama yaitu proses input data login, yang kedua adalah 
proses validasi login. DFD proses Login dapat dilihat pada gambar 4.

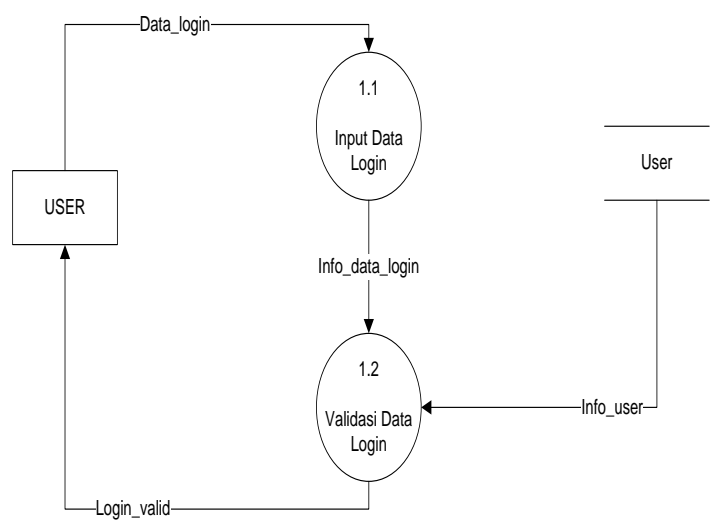

Gbr.4 DFD Level 2 Proses Login

DFD level 2 Proses 2.0

Proses kedua adalah proses pengolahan data penduduk digunakan untuk mengelola penduduk yang dilakukan oleh user. Pada proses ini terdapat empat proses yaitu proses tambah, ubah, hapus dan pencarian data penduduk. DFD proses pengolahan data penduduk dapat dilihat pada gambar 5 .

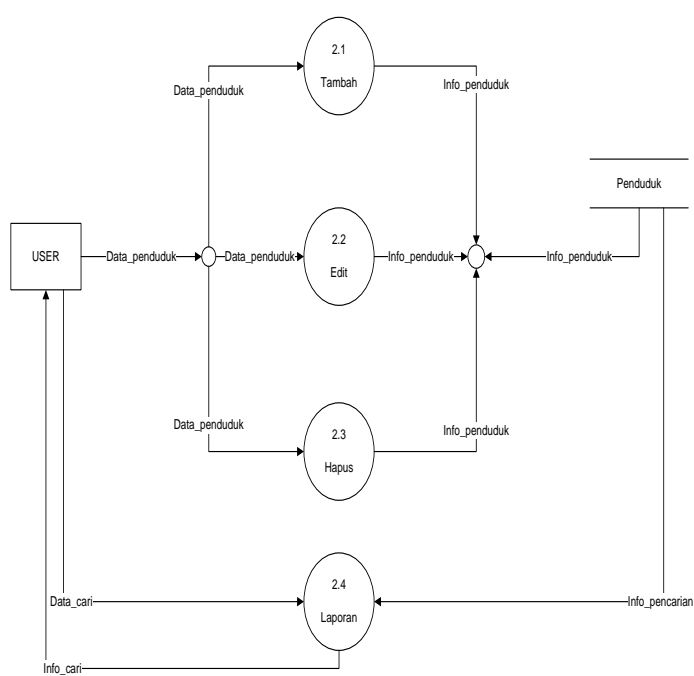

Gbr.5 DFD Level 2 Proses 2.0 Pengolahan data Penduduk

DFD level 2 Proses 3.0

Proses ketiga adalah pengolahan data perpindahan, digunakan untuk mengelola penduduk yang akan melakukan perpindahan. Pada proses ini terdapat dua proses utama yaitu proses perpindahan masuk, yang kedua adalah proses perpindahan keluar. DFD proses pengolahan data perpindahan dapat dilihat pada gambar 6.

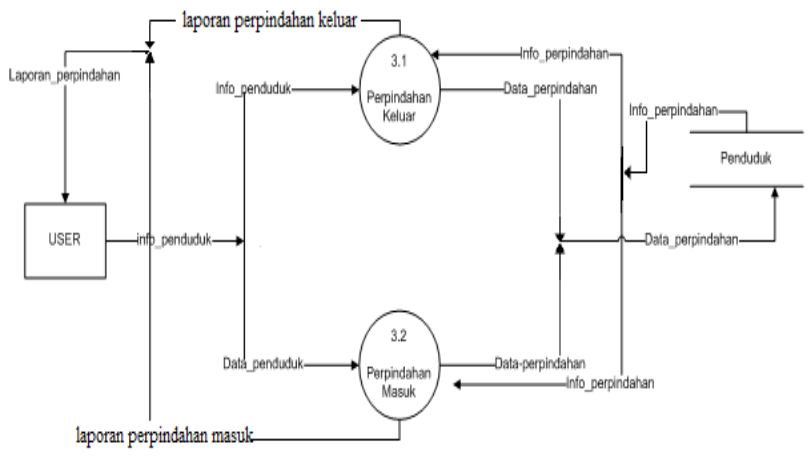

Gbr.6 DFD Level 2 Proses 3.0 Pengolahan data Perpindahan

DFD level 2 Proses 4.0

Pada proses Laporan ini yaitu data penduduk yang telah di kelolah oleh user dan disimpan dalam database maka dapat disajikan dalam bentuk laporan. DFD proses Laporan dapat dilihat pada gambar 7.

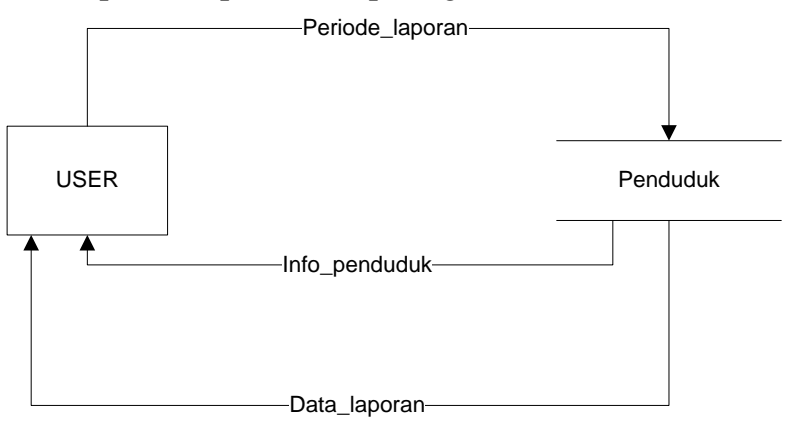

Gbr.7 DFD Level 2 Proses 4.0 Pengolahan data Laporan

DFD Level 3 Proses 3.1

Proses DFD level 3 proses 3.1 adalah proses Input data perpindahan keluar. Pada proses ini terdapat tiga proses utama yaitu proses input pindah keluar, simpan data pindah keluar dan cetak data pindah keluar. DFD proses ini dapat dilihat pada gambar 7 .

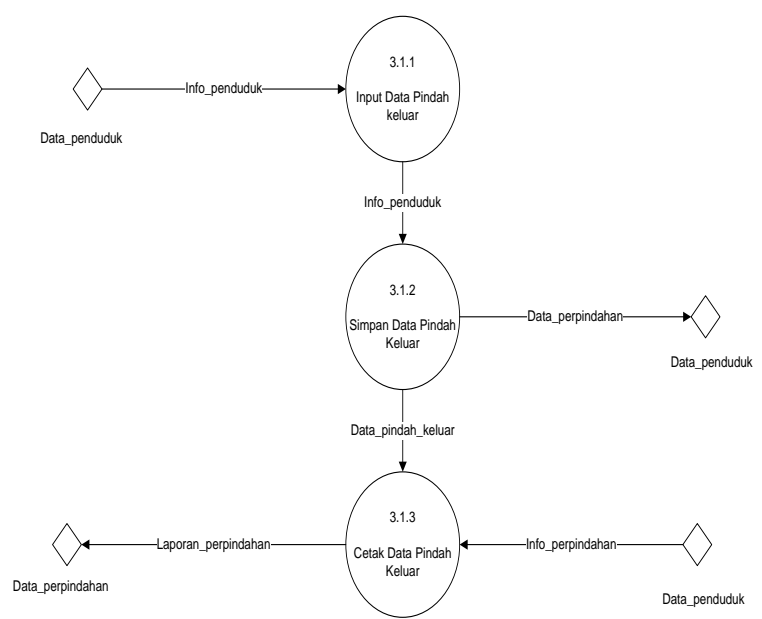

Gbr.8 DFD Level 3 Proses 3.1 Pengolahan data Perpindahan Keluar 
DFD Level 3 Proses 3.2

Proses DFD level 3 proses 3.2 adalah proses Input data perpindahan masuk. Pada proses ini terdapat tiga proses utama yaitu proses input pindah masuk, simpan data pindah masuk dan cetak data pindah masuk. DFD proses ini dapat dilihat pada gambar 9:

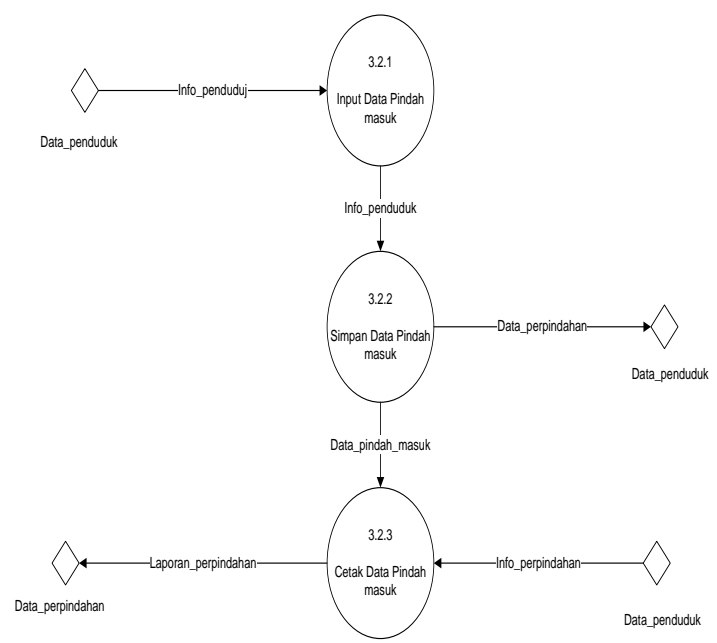

Gbr.9 DFD Level 3 Proses 3.2 Pengolahan data Perpindahan Masuk

\section{Kamus data}

Data yang mengalir pada sistem dari satu proses ke proses yang lain dapat diuraikan sebagai berikut :

- Data Login : username + password

- Info Login : id user

- Data Pengguna : username

- Detail Pengguna : username + password

- Data Penduduk : id penduduk + no.ktp + nama + tempat lahir + tanggal lahir + alamat

- Detail Penduduk : no. ktp + nama + tempat lahir + tanggal lahir + jenis kelamin + status + agama + tinggi badan + berat badan + alamat $+\mathrm{rt}+\mathrm{rw}+$ kecamatan + kecamatan + provinsi kabupaten + telepon + pekerjaan + alamat pekerjaan + pendidikan terakhir + gol.darah + jumlah anggota keluarga

- Data Laporan : rekap data penduduk, data jumlah penduduk, dan data penduduk yang masuk kemudian di cetak.

\section{Perancangan Sistem}

Tahap perancangan merupakan kelanjutan dari proses analisis dimana dilakukan terhadap perubahan perubahan sistem yang sedang berjalan. Hal ini dilakukan untuk mengatasi kekurangan yang ada, memudahkan pekerjaan yang dilakukan oleh orang yang terlibat dan menghemat waktu pekerjaan.

Perancangan Data

Perancangan data adalah kumpulan dari data yang saling berhubungan yang diorganisasi sedemikian rupa agar kemudian dirancang dapat dimanfaatkan lagi dengan cepat dan mudah (Abdul Kadir, 2002: 39).

Skema Relasi

Adapun skema relasi yang terdapat dalam Sistem pengolahan data kependudukan Kecamatan Medan kota adalah:

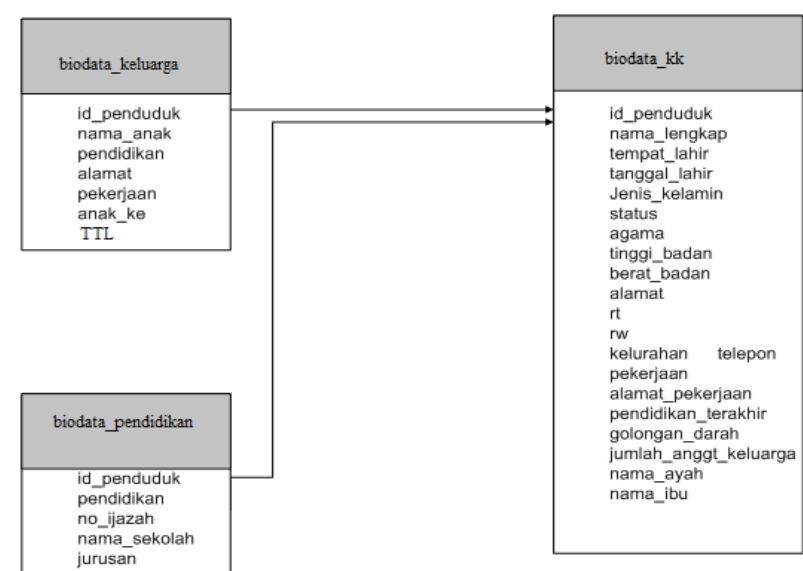

Gbr.10 Skema Relasi

Perancangan Antarmuka

Interface atau antarmuka merupakan tampilan dari suau program aplikasi yang berperan sebagai media komunikasi yang digunakan sebagai sarana berdialog antara program dengan user. Sistem yang akan dibangun diharapkan menyediakan interface yang mudah dipahami dan digunakan oleh user.

Perancangan antarmuka dari aplikasi Sistem Pengolahan penduduk di Medan Kota adalah sebagai berikut :

1. Perancangan Antarmuka Splash

2. Perancangan Antarmuka Halaman Login

3. Perancangan Antarmuka Halaman Menu Utama

4. Perancangan Antarmuka Halaman Menu Pengolahan Data Penduduk

5. Perancangan Antarmuka Halaman Menu Pencarian Data Penduduk

6. Perancangan Antarmuka Halaman Menu Data Perpindahan Keluar

7. Perancangan Antarmuka Halaman Menu Data Perpindahan Masuk

8. Perancangan Antarmuka Halaman Menu Data Laporan

9. Perancangan Antarmuka Halaman Menu Grafik Pertumbuhan.

\section{HASIL DAN PEMBAHASAN}

\section{A. Implementasi Sistem}

Setelah tahap analisis dan perancangan sistem, tahap selanjutnya adalah tahap implementasi. Tujuan dari tahap implementasi ini adalah untuk memastikan perangkat lunak yang dibuat dapat berjalan secara sesuai dengan yang diinginkan. Setelah implementasi maka dilakukan pengujian sistem, dimana akan terlihat kekurangan-kekurangan pada perangkat lunak untuk selanjutnya diadakan pengembangan sistem. Berikut ini adalah implementasi sistem pengolahan data penduduk di Kecamatan Medan Kota.

\section{B. Implementasi Antar Muka}

Pada bagian ini program Sistem Pengolahan Data Penduduk dapat disajikan langsung agar pengguna 
dapat melihat tahapan - tahapan apa saja yang dapat dilakukan oleh pengguna untuk menggunakan aplikasi Sistem Pengolahan Data Penduduk. Tampilan menu login dapat dilihat pada gambar 11 .

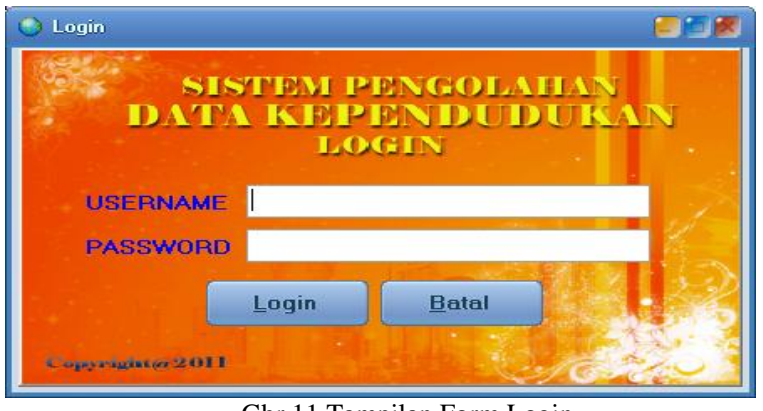

Gbr.11 Tampilan Form Login

Setelah masuk ke menu Login user, maka akan masuk dalam menu utama Sistem Pengolahan Data Kependudukan. Tampilan menu utama dapat dilihat pada gambar 12

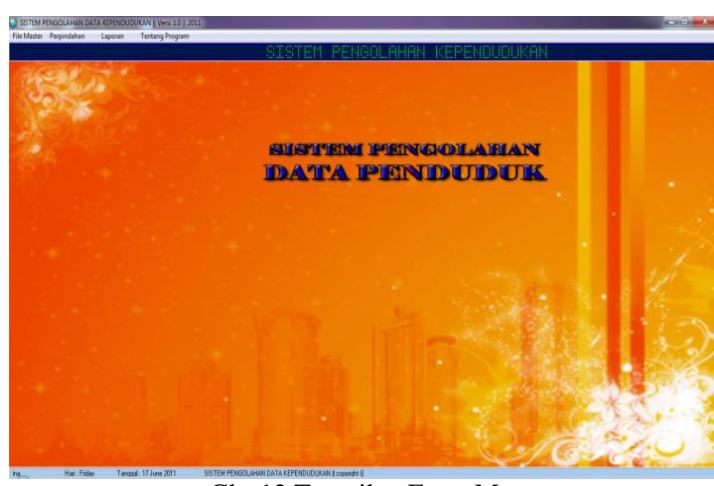

Gbr.12 Tampilan Form Menu

Setelah masuk ke menu Utama, maka untuk masuk dalam menu Pengolahan biodata Penduduk tampilannya dapat dilihat pada gambar 13

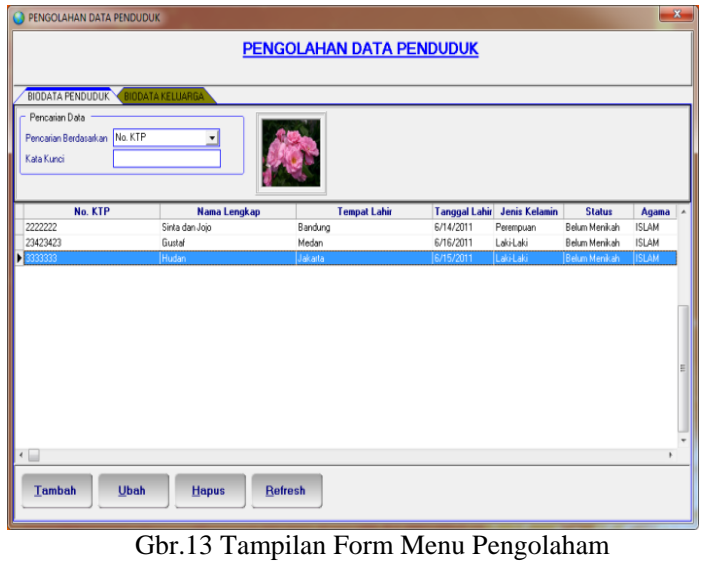

Setelah masuk ke menu Pengolahan Data Penduduk Biodata Keluarga, maka untuk masuk dalam menu Pengolahan Data Penduduk Biodata tampilannya dapat dilihat pada gambar 14

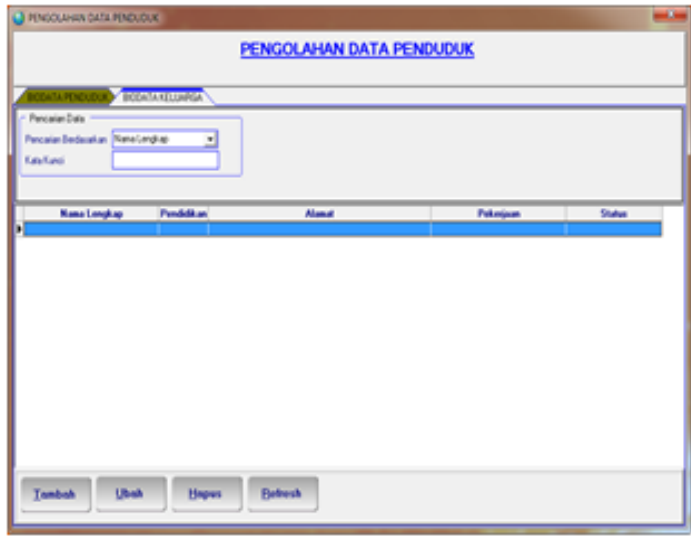

Gbr.14 Tampilan Form Menu Pengolaham Biodata

Setelah masuk ke menu Pencarian Data Penduduk berdasarkan Biodata Penduduk, maka untuk masuk dalam menu Pencarian Data Penduduk Biodata Penduduk tampilannya dapat dilihat pada gambar 15 .

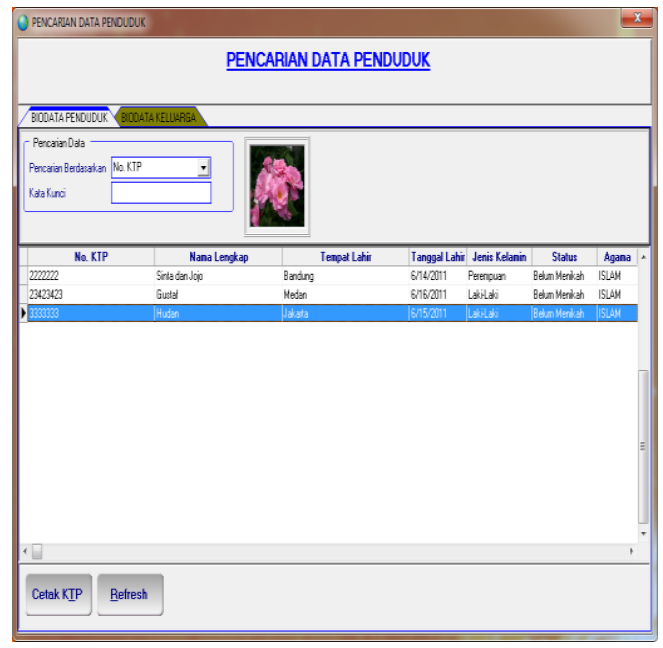

Gbr.15 Tampilan Form Menu Pencarian Biodata Penduduk

Setelah masuk ke menu Grafik Pertumbuhan Penduduk berdasarkan Jenis Kelamin, maka untuk masuk dalam menu Grafik pertumbuhan berdasarkan Jenis Kelamin tampilannya dapat dilihat pada gambar 16.

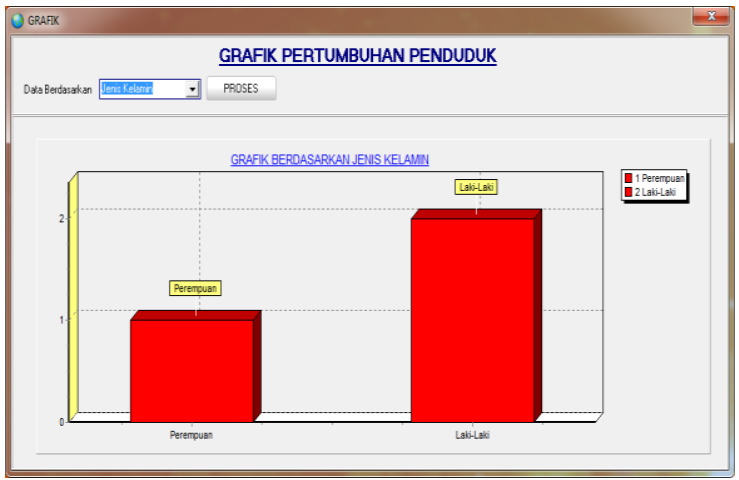

Gbr.16 Tampilan Form Menu Grafik Berdasarkan Jenis Kelamin 
Kemudian untuk masuk ke menu Laporan, maka untuk masuk dalam menu Laporan tampilannya dapat dilihat pada gambar 17 .

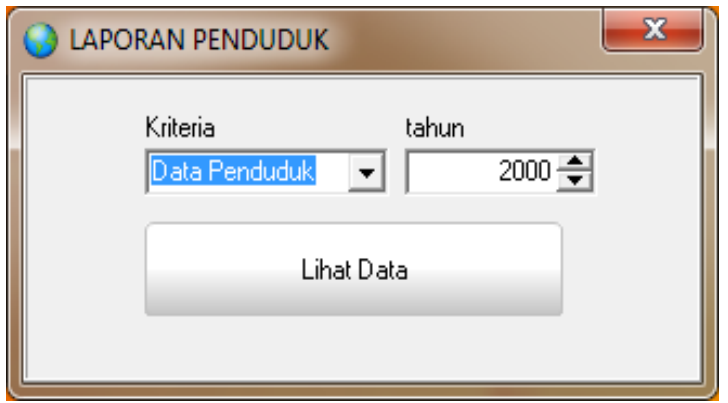

Gbr.17 Tampilan Form Menu Laporan

Kemudian untuk masuk ke Laporan Cetak Data Penduduk maka untuk masuk dalam form Cetak tampilannya dapat dilihat pada gambar 18 .

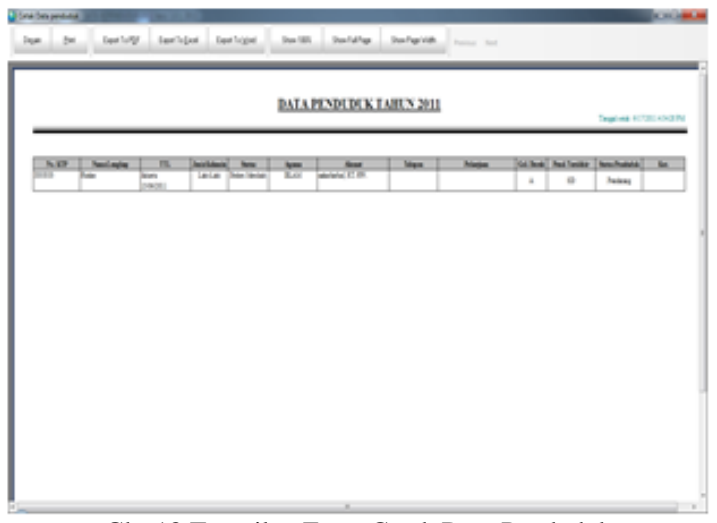

Gbr.18 Tampilan Form Cetak Data Penduduk

\section{Pengujian}

Pengujian perangkat lunak ini menggunakan metode pengujian black box. Pengujian black box berfokus pada persyaratan fungsional perangkat lunak, yaitu masukkan pada sistem dan keluaran pada sistem.

Pengujian aplikasi sistem pengolahan data penduduk ini menggunakan data uji berdasarkan nilai dari Kecamatan Medan Kota. Pengujian Sistem Pengolahan Data Penduduk dapat dilihat pada tabel I.

TABEL I

PENGUJIAN SISTEM PENGOLAHAN DATA PENDUDUK

\begin{tabular}{|c|l|l|}
\hline \multirow{2}{*}{ Kelas Uji } & \multicolumn{1}{|c|}{ Butir Uji } & $\begin{array}{l}\text { Jenis } \\
\text { Pengujian }\end{array}$ \\
\hline \multirow{4}{*}{ Login } & $\begin{array}{l}\text { Validasi user } \\
\text { name }\end{array}$ & Black Box \\
\cline { 2 - 3 } & $\begin{array}{l}\text { Validasi } \\
\text { password }\end{array}$ & Black Box \\
\hline \multirow{5}{*}{$\begin{array}{c}\text { Pengolahan data } \\
\text { Penduduk }\end{array}$} & $\begin{array}{l}\text { Tambah data } \\
\text { Penduduk }\end{array}$ & Black Box \\
\cline { 2 - 3 } & $\begin{array}{l}\text { Ubah data } \\
\text { Penduduk }\end{array}$ & Black Box \\
\cline { 2 - 3 } & $\begin{array}{l}\text { Hapus data } \\
\text { Penduduk }\end{array}$ & Black Box \\
\hline
\end{tabular}

\begin{tabular}{|c|c|c|}
\hline \multirow{3}{*}{$\begin{array}{c}\text { Pengolahan } \\
\text { Data Pencarian }\end{array}$} & $\begin{array}{l}\text { Cari } \\
\text { Berdasarkan } \\
\text { Biodata } \\
\text { Keluarga }\end{array}$ & Black Box \\
\hline & $\begin{array}{l}\text { Cari } \\
\text { Berdasarkan } \\
\text { Biodata } \\
\text { Penduduk }\end{array}$ & Black Box \\
\hline & $\begin{array}{l}\text { Grafik } \\
\text { Berdasarkan } \\
\text { Jenis kelamin }\end{array}$ & Black Box \\
\hline \multirow{3}{*}{$\begin{array}{c}\text { Pengolahan data } \\
\text { Perpindahan }\end{array}$} & $\begin{array}{l}\text { Input Data } \\
\text { Penduduk } \\
\text { Keluar } \\
\end{array}$ & Black Box \\
\hline & Input Data & Black Box \\
\hline & $\begin{array}{l}\text { Penduduk } \\
\text { Masuk }\end{array}$ & Black Box \\
\hline \multirow{4}{*}{$\begin{array}{l}\text { Pengolahan data } \\
\text { Laporan }\end{array}$} & $\begin{array}{l}\text { Berdasarkan } \\
\text { Penduduk } \\
\text { Masuk } \\
\end{array}$ & Black Box \\
\hline & $\begin{array}{l}\text { Berdasarkan } \\
\text { Penduduk } \\
\text { Pindah }\end{array}$ & Black Box \\
\hline & $\begin{array}{l}\text { Berdasarkan } \\
\text { Tahun }\end{array}$ & Black Box \\
\hline & $\begin{array}{l}\text { Cetak Data } \\
\text { Penduduk }\end{array}$ & Black Box \\
\hline
\end{tabular}

Kasus dan Hasil Pengujian

Pengujian data normal login dapat dilihat pada tabel II.

TABEL II

PENGUJIAN DATA NORMAL LOGIN

\begin{tabular}{|c|c|c|c|}
\hline \multicolumn{4}{|c|}{ Kasus dan Hasil Uji ( Data Normal ) } \\
\hline $\begin{array}{c}\text { Data } \\
\text { Masukkan }\end{array}$ & $\begin{array}{c}\text { Yang } \\
\text { diharapkan }\end{array}$ & Pengamatan & Hasil \\
\hline $\begin{array}{l}\text { User name } \\
\text { dan } \\
\text { password: } \\
\text { ina }\end{array}$ & $\begin{array}{l}\text { Login } \\
\text { berhasil. } \\
\text { Linkuser } \\
\text { pada menu } \\
\text { file akan } \\
\text { aktif. }\end{array}$ & $\begin{array}{l}\text { User name } \\
\text { dan } \\
\text { password } \\
\text { sesuai } \\
\text { dengan table } \\
\text { Tuser. } \\
\text { Login } \\
\text { berhasil. } \\
\text { Linkuser } \\
\text { pada menu } \\
\text { file akan } \\
\text { aktif. }\end{array}$ & $\begin{array}{l}\text { Diteri } \\
\text { ma }\end{array}$ \\
\hline
\end{tabular}



III.

Pengujian data salah login dapat dilihat pada tabel

TABEL III

PenguJian Data SALAh LogiN

Kasus dan Hasil Uji ( Data Normal )

\begin{tabular}{|c|c|c|c|}
\hline $\begin{array}{c}\text { Data } \\
\text { Masukkan }\end{array}$ & $\begin{array}{c}\text { Yang } \\
\text { diharapka } \\
n\end{array}$ & $\begin{array}{c}\text { Pengamata } \\
n\end{array}$ & Hasil \\
\hline $\begin{array}{l}\text { Data user } \\
\text { name tidak } \\
\text { terdaftar }\end{array}$ & $\begin{array}{l}\text { Tidak } \\
\text { dapat login } \\
\text { dan } \\
\text { menampilk } \\
\text { an pesan } \\
\text { "Silahkan } \\
\text { terlebih } \\
\text { Dahulu isi } \\
\text { username" }\end{array}$ & $\begin{array}{l}\text { User tidak } \\
\text { dapat login } \\
\text { dan } \\
\text { menampilka } \\
\text { n pesan } \\
\text { "Silahkan } \\
\text { terlebih } \\
\text { Dahulu isi } \\
\text { username". }\end{array}$ & $\begin{array}{l}\text { Diteri } \\
\text { ma }\end{array}$ \\
\hline $\begin{array}{l}\text { Data } \\
\text { password } \\
\text { tidak valid }\end{array}$ & $\begin{array}{l}\text { Tidak } \\
\text { dapat login } \\
\text { dan } \\
\text { menampilk } \\
\text { an pesan } \\
\text { "Silahkan } \\
\text { terlebih } \\
\text { Dahulu isi } \\
\text { password" }\end{array}$ & $\begin{array}{l}\text { User tidak } \\
\text { dapat login } \\
\text { dan } \\
\text { menampilka } \\
\text { n pesan } \\
\text { "Silahkan } \\
\text { terlebih } \\
\text { Dahulu isi } \\
\text { username". }\end{array}$ & $\begin{array}{l}\text { Diteri } \\
\text { ma }\end{array}$ \\
\hline
\end{tabular}

\section{KESIMPULAN}

\section{A. Kesimpulan}

Berdasarkan semua proses dalam membangun aplikasi ini dapat diambil kesimpulan sebagai berikut :

1. Sistem Pengolahan Data Penduduk di Kecamatan Medan Kota ini dapat membantu user untuk menentukan jumlah penduduk.

2. Sistem Pengolahan Data Penduduk di Kecamatan Medan Kota ini dapat membantu user untuk melakukan pencarian data penduduk.

3. Sistem Pengolahan Data Penduduk di Kecamatan Medan Kota ini dapat membantu user untuk membuat Kartu Keluarga (KK) penduduk.

\section{B. Saran}

Berdasarkan semua proses dalam membangun aplikasi ini dapat disarankan beberapa hal berikut :

1. Sistem Pengolahan Data Penduduk di Kecamatan Medan Kota ini dapat lebih dikembangkan lagi sesuai dengan kebutuhan user.

2. Sistem Pengolahan Data Penduduk di Kecamatan Medan Kota ini dapat dikembangkan dengan metode yang berbeda.

\section{REFERENSI}

[1] Ariyus, Doni \& Rum Andri K.R. 2008. Komunikasi Data. Yogyakarta : Andi Offest

[2] Kadir, Abdul.2002. Pengenalan Sistem Informasi. Jakarta : Andi Offset

[3] Kadir, Abdul. 2005. Pemrograman Delphi. Yogyakarta : Penerbit Andi

[4] Kurniawan, Wiharsono. 2007. Computer started guide. Yogyakarta : Andi Offset.

[5] Simarmata, Janer. 2006. Pengenalan Teknologi Komputer dan Informasi. Yogyakarta :Andi Offset

[6] Saladin, Anjik, S.kom. 2005. Pengenalan Bahasa Pemograman Borland Delphi 7. Jakarta : Gramedia

[7] Santoso, Teguh. 2003. Prinsip Dasar Sistem Informasi dan Komunikasi Data. Jakarta: Graha Ilmu

[8] Heriyadi. 2002. Terbang Bersama Delphi dalam Majalah Info Delphi, Edisi November. 